\title{
PERAN IBU DALAM MENGAJARKAN MODERASI BERAGAMA PADA ANAK DI MASA PANDEMI COVID 19
}

\author{
Heny Kusmawati \\ Program Studi Pendidikan Agama Islam, Sekolah Tinggi Agama \\ Islam Pati \\ kusmawati.heny@gmail.com
}

\section{Anista Ika Surachman}

Program Studi Pendidikan Agama Islam, Sekolah Tinggi Agama IslamPati

anistasurachman@gmail.com

DOI: 10.20885/tarbawi.vol12.iss2.art2

\begin{abstract}
Starting from the hadith narrated by narrated by Imam Muslim which means: "every human being is born upon fitrah. His parents made him Jewish, Christian or Majusi." From this hadith, it is clear that parents have big role in shaping children religiosity. Thus, the obligation of parents is to make children have religious maturity by doing religious moderation so that children develop an attitude of respect for other religions. Moreover, education during the Covid-19 pandemic which is more conducted at home makes the mother figure a determinant of the success of teaching religious moderation in children. The purpose of writing this article is to describe mothers and how to teach religious moderation to children during the Covid19 pandemic. The research is qualitative research with grounded theory method, it used interview in collecting data with the help from related written references on the theory of religious moderation. The results of this article concluded 1) the urgency to prevent children from radical literacy in cyberspace, and 2) the stages of teaching Pancasila values that are in accordance with religious moderation in the neighborhood.
\end{abstract}

Keywords: Mother; Education; Moderation; Religion 


\title{
$e^{\text {I-Tarbawj Heny Kusmawati \& Anista Ika Surachman }}$
}

\begin{abstract}
Abstrak
Bertolak dari hadis yang diriwayatkan oleh Imam Muslim dengan arti, "setiap manusia dilahirkan di atas fitrah. Kedua orang tuanya yang menjadikannya Yahudi, Nasrani, atau Majusi." Dari hadist ini, orang tua memiliki peran penting dalam membentuk karakter keberagamaan dari anak. Maka, kewajiban orangtua adalah membuat anak memiliki kematangan beragama dengan melalukan moderasi beragama sehingga anak menumbuhkan sikap menghargai agama lain. Apalagi pendidikan selama pandemi Covid-19 yang lebih bertumpu di rumah, menjadikan sosok ibu sebagai salah satu penentu keberhasilan pengajaran moderasi beragama pada anak. Tujuan penulisan artikel ini adalah mendeskripsikan peran ibu dan cara mengajarkan moderasi beragama pada anak masa pandemi Covid-19. Penelitian ini merupakan penelitian kualitatif dengan metode grounded theory, dengan menggunakan teknik wawancara dalam pengumpulan data dibantu dengan data-data tertulis dari sumber referensi tertulis yang terkait dengan teori moderasi beragama. Hasil tulisan artikel ini menyimpulkan 1) upaya untuk mencegah anak-anak dari literasi radikal di internet dan 2) tahapan mengajarkan nilai-nilai pancasila yang sesuai dengan moderasi keberagamaan di lingkungan tempat tinggal.
\end{abstract}

Kata kunci: Ibu; Pendidikan; Moderasi; Agama

\section{PENDAHULUAN}

Pendidikan melemah, kegiatan sekolah terhenti secara masif, pembelajaran offline menjadi pembelajaran dalam jaringan, dan guru melakukan aktivitas terkoneksi secara online, itulah beberapa dampak Covid-19 atau yang terkenal dengan virus corona. Tidak pernah disangka bahwa pembelajaran yang dilaksanakan secara tatap muka di kelas-kelas akan terhenti kurang lebih hampir 1 tahun dari Maret 2020 sampai bulan Maret 2021. Terlebih berhentinya pembelajaran offline ini belum 
diketahui akan berlangsung sampai kapan. Adanya perubahan model pembelajaran tersebut memunculkan stigma bahwa di masa pandemi, generasi baby boomers tergantikan oleh Gen Z sehingga dibutuhkan strategi pembelajaran terbaru di era disrupsi ini (Heny 2019, 1). Di bidang pendidikan, pandemi Covid-19 juga telah mengubah pola pendidikan di sekolah pada umumnya dan pendidikan yang dilakukan oleh ibu pada khususnya. Anak-anak usia sekolah mengalami perubahan yang drastis terkait pelaksanaan pembelajaran yang ia ikuti.

Usia anak-anak yang berkisar dari 7-12 tahun adalah usia dimana anak dikenalkan lebih mendalam dengan agama. Literatur lain juga menjelaskan bahwa usia anak-anak, khususnya usia dini merupakan momentum yang tepat untuk membentuk watak, kepribadian, dan karakter (Jasuri 2015, 16). Hadis yang diriwayatkan oleh Al-Baihaqi dan Ath-Thabarani dalam Al-Mu'jamul Kabir menjelaskan bahwa anak adalah subjek dalam kehidupan beragama yang dibentuk oleh orang tua. Al-Imam Muslim rahimahullah meriwayatkan dengan lafaz:

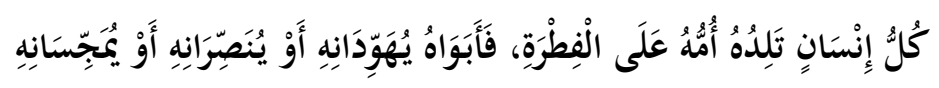

"Setiap manusia dilahirkan oleh ibunya di atas fitrah. Kedua orang tuanya yang menjadikannya Yahudi, Nasrani, atau Majusi."

Hadis tersebut secara eksplisit menunjukkan bahwa anak dibentuk dari pengajaran orang tuanya, dimana mereka akan menjadi Yahudi, Nasrasi atau Majusi. Tidak dapat dipungkiri, apabila orang tua beragama Islam secara rasionalitas anak juga akan beragama Islam. Hal tersebut dikarenakan anak belum 


\section{$e^{\text {I-Tarbawj Heny Kusmawati \& Anista Ika Surachman }}$}

mampu memilih agama mana yang mereka inginkan, sehingga orangtualah yang menentukan agama yang akan mereka anut.

Terkait pendidikan anak dalam keluarga, ibu menjadi sosok yang berperan penting dalam pengajaran anak. Salah satu peran ibu dalam mendidik anak menurut Syekh Sofiudin bin Fadli Zain adalah sebagai pendidik ketauhidan, sebagai teladan, dan sebagai pengawas (Imam 2015). Ketiga peran tersebut berkaitan erat dengan bagaimana mendidik anak dalam moderasi beragama. Kondisi pandemi Covid-19 seperti sekarang, memperkuat posisi ibu sebagai pengajar atau transfer of knowledge dan pendidik (transfer of value) bagi anak-anak mereka sendiri. Ibu dituntut untuk mampu memilihkan referensi pembelajaran yang memiliki muatan nilai-nilai keagamaan yang tidak memiliki paham radikal dan memberikan pengetahuan kepada anak bahwa beragama itu penuh kedamaian. Keseimbangan dalam memilih konten pembelajaran penting dilakukan agar anak tidak menjadi fanatik terhadap suatu ajaran tertentu atau menganut pahampaham radikalisme.

Pada buku karangan Kementrian Agama RI, dijelaskan bahwa kedamaian didapatkan dengan moderasi beragama yang berarti cara beragama jalan tengah (Kementrian Agama RI 2019). Kata jalan tengah dapat dipahami bahwa tidak ada pola pikir yang membenarkan salah satu agama atau keyakinan dan menyalahkan agama atau keyakinan yang lain. Sebagai contoh melakukan jihad karena alasan membela umat dengan melakukan pengeboman di tempat ibadah umat lain merupakan salah satu tindakan yang tidak mencerminkan moderasi beragama. 
Mengutip pengalaman dari Imam Shamsi Ali, imam Islamic Center di NEW York, Amerika Serikat dan Direktur Jamaica Muslim Center, dalam tulisannya di Republika Online beliau menulis pengalamannya bertemu dengan seorang nonmuslim dalam perjalanan dari rumah ke kota. Beliau menyampaikan, "Moderate are those who lives as as anyone else. Dress as others, partying as others, eating and drinking as others, marrying as others." (Moderat adalah mereka yang hidup seperti halnya orang lain. Berpakaian seperti orang lain, pergi ke pesta seperti orang lain, makan dan minum seperti orang lain, menikah seperti orang lain). Pernyataan persebut diartikan bahwa moderasi adalah kehidupan normal dengan pola pikir yang seimbang antara psikologis, agama, dan rasionalitas.

Mengadaptasi buku saku kemenag RI (Kementrian Agama RI 2019, 4) dijelaskan bahwa proses moderasi beragama dapat dilakukan melalui tahap memahami ajaran agama, sekaligus mengamalkannya dengan adil dan seimbang. Hal ini dilakukan untuk menghindari perilaku yang berlebihan dalam mengamalkan suatu hal. Pemahaman yang kurang tepat adalah mengartikan moderasi beragama sebagai memoderasi agama. Hal tersebut dianggap kurang sesuai karena dalam agama sudah mengandung prinsip moderasi melalui ajaran untuk berlaku adil dan seimbang. Karena sejatinya setiap agama pasti mengajarkan kebaikan pada umatnya. Sehingga apa yang dimaksud dengan moderasi beragama bukanlah memoderasikan agamanya, namun lebih pada perilaku beragamanya. Perilaku tersebut dapat dilakukan dengan menghindari perkataan atau perbuatan yang ekstrem, tidak 


\section{$e^{\text {I-Tarbawj Heny Kusmawati \& Anista Ika Surachman }}$}

adil, dan berlebih-lebihan. Kodratnya, manusia adalah makhluk yang memiliki pengetahuan yang terbatas dan memerlukan esensi kebenaran pengetahuan Tuhan yang luas sehingga tidak terkurung dalam pola pikir yang sempit. Keragaman tafsir terkait suatu hal, termasuk tafsir tentang ajaran agama, biasanya muncul sebagai dampak dari upaya manusia untuk memahami teks ajaran agama. Pada hakikatnya, kebenaran yang sesungguhnya hanyalah milik Allah, sedangkan kebenaran dari penafsiran manusia sifatnya hanya relatif (Kementrian Agama RI 2019, ii-iii). Hal itu menjadi alasan kuat untuk mengajarkan moderasi beragama pada setiap individu terutama anak-anak, karena mereka masih belajar bagaimana cara menghargai teman sejawat yang berbeda agama, berbeda mazhab bahkan berbeda pola pikir tentang penafsiran dari sebuah agama.

Dalam Islam telah dikatakan bahwa agama yang baik adalah agama rahmatan lil alamin, atau agama yang membawa kedamaian. Fungsi agama bagi manusia adalah sebagai pedoman kehidupan tentang cara menolong, berbagi dengan orang lain, dan berlomba-lomba dalam kebaikan. Hal itu secara tidak langsung menyiratkan bahwa kedamaian adalah ciri penting dalam keberagamaan. Apabila berkaca dari realitas tersebut, Indonesia adalah negara yang potensial untuk mengajarkan moderasi beragama secara langsung. Sedikitnya ada 6 agama yang diakui oleh pemerintah Indonesia, yaitu Islam, Kristen, Budha, Hindu, Katolik, dan Konghucu. Keberagaman tersebut dapat dimanfaatkan untuk mengajarkan pada anak terkait moderasi beragama pada setting lingkungan yang sebenarnya. Berdasarkan latar belakang tersebut maka 
tulisan ini mengkaji tentang ibu dan cara mengajarkan moderasi beragama pada anak pada masa pandemi Covid-19. Fokus pembahasannya adalah urgensi dalam pencegahan pengaksesan literasi radikalisme pada anak di dunia maya dan tahapan mengajarkan nilai-nilai pancasila yang sesuai dengan moderasi keberagamaan di lingkungan tempat tinggal.

Beberapa penelitian sebelumnya yang relevan dengan penelitian tersebut, salah satunya dilakukan oleh M Fahri dan A Zainuri pada tahun 2020 dengan fokus penelitian "Moderasi Beragama di Indonesia" (M Fahri dan Zainuri 2020, 95-100). Penelitian tersebut menunjukkan bahwa radikalisme atas nama agama dapat diberantas melalui pendidikan Islam yang moderat dan inklusif. Moderasi beragama dapat ditunjukkan melalui sikap tawazun (berkeseimbangan), i'tidal (lurus tegas), tasamuh (toleransi),musawah (egaliter), syura (musyawarah), islah (reformasi), aulawiyah (mendahulukan yang prioritas), dan tathawwur wa ibtikar (dinamis dan inovatif). Penelitian lain dengan judul "Internalisasi Moderasi Beragama Dalam Kurikulum Pesantren" menemukan bahwa moderasi beragama pada kurikulum pesantren mampu menjawab kebutuhan yang saat ini menjadi problematika masa kini yaitu ekstrimisme dan radikalisme (Khatimah 2008, 1). Selanjutnya, penelitian Hani Hiqmatunisa dan Ashif Az Zafi tentang "Penerapan Nilai-Nilai Moderasi Islam dalam Pembelajaran Fiqih di PTKIN Menggunakan Konsep Problem Basic Learning" menyatakan bahwa penanaman nilai moderat diharapkan PTKIN dapat mempersiapakan warga Negara Indonesia yang beragama Islam dengan tetap menjaga nilai-nilai kearifan, toleransi, dan tidak radikal (Hani 2019). 


\section{$e^{\text {I-Tarbawj Heny Kusmawati \& Anista Ika Surachman }}$}

Penelitian lain yang menguatkan pentingnya moderasi dilakukan oleh Edi Junaedi, yang hasilnya menyatakan moderasi membawa keadilan bagi umat beragama dan menjaga persatuan dan kesatuan (Edy 2019). Sedangkan apabila dikaji dari segi pendidikan, penelitian Edy Sutrisno yang berjudul "Aktualisasi Moderasi Beragama di Lembaga Pendidikan" menunjukkan hasil dalam upaya mewujudkan moderasi beragama di masyarakat multikultural, yang perlu dilakukan adalah menjadikan lembaga pendidikan sebagai basis laboratorium moderasi beragama dan melakukan pendekatan sosio-religius dalam beragama dan bernegara. (Edi 2019) Sebagai upaya memperluas khazanah pengetahuan, penelitian ini fokus untuk mengkaji upaya mengajarkan moderasi Islam pada anak pada masa pandemic Covid-19 melalui peran ibu.

\section{METODE PENELITIAN}

Penelitian ini dilakukan dengan menggunakan pendekatan kualitatif. Pendekatan tersebut dilakukan dengan menelusuri informasi dan mengumpulkan data untuk mendapatkan pemahaman yang mendalam dari gejala sentral (Creswell dalam Raco, 2010: 22-28). Data-data dalam penelitian ini dikumpulkan dari informasi-informasi yang diberikan oleh informan melalui Google Form. Aplikasi tersebut dipilih karna mengakomodir kebutuhan pengumpulan data dengan kondisi yang serba terbatas karna adanya pandemi. Aplikasi ini juga dapat mengumpulkan data dan informasi dari informan tanpa harus bertemu langsung dengan waktu yang relatif singkat. Subjek dalampenelitian ini adalah ibu-ibu Desa Babalan, 
Kecamatan Gabus, Kabupaten Pati yang memiliki anak usia 712 tahun. Penelitian digunakan untuk mengetahui seberapa besar peran ibu dalam mengajarkan moderasi beragama pada anaknya melalui pencegahan mengakses literasi radikalisme di dunia maya dan tahapan mengajarkan moderasi agama pada anak di lingkungan tempat tinggal. Tahapan penelitian dilakukan dengan menyusun pertanyaan yang akan diajukan pada informan dalam Google Form, kemudian menyebarkan pertanyaan yang telah ditulis dalam Google Form melali Whatsapp, dan terakhir menganalisis data-data yang telah terkumpul.

Rujukan untuk penelitian ini adalah teori moderasi beragama yang dirumuskan oleh Kementrian Agama RI. Teori tersebut menyebutkan ada tiga dimensi yang perlu dikembangkan untuk mewujudkan moderasi beragama, yaitu: nilai kemanusiaan, kesepakatan bersama, dan ketertiban umum (Kemenag RI 2019, 1). Pada proses mengajarkan moderasi beragama pada anak, ketiga hal tersebut dapat diadaptasi oleh ibu dalam mendidik anaknya.

Penelitian ini menggunakan Teknik analisis data kualitatif dan mengacu pada metode grounded theory (Budiasih 2014, 1927). Tahap yang dilakukan melalui teori ini adalah membuat kode-kode dan kategori terhadap data yang dikunpulkan. Pada penelitian ini, data yang dikumpulkan berupa fenomena ibu dan cara mengajarkan moderasi beragama pada anak di masa pandemi corona. Analisis data dilakukan melalui beberapa tahap, diantaranya: identifikasi data, pengkategorian dan penguraian data, serta penyajian data. Identifikasi dilakukan terhadap fenomena penggunaan moderasi beragama. 


\section{el-Tarbawj Heny Kusmawati \& Anista Ika Surachman}

Selanjutnya proses pengkategorian dan penguraian gejala diakukan terhadap data-data yang diperoleh dalam wawancara yang dilakukan melalui google form dan whatapps. Langkah terakhir yaitu menggabungkan data-data dengan kategori yang sama dalam susunan yang baru dengan menerapkan proses berfikir induktif dan deduktif untuk menganalisis data terkait ibu dan cara mengajarkan moderasi beragama pada anak di masa pandemi corona.

\section{HASIL DAN PEMBAHASAN}

Hasil studi ini akan membahas dua poin utama yaitu upaya dalam pencegahan mengakses literasi yang mengandung radikalisme pada anak dan tahapan mengajarkan nilai-nilai pancasila yang sesuai dengan moderasi keberagamaan di lingkungan tempat tinggal.

\section{Upaya dalam Pencegahan Literasi Radikalisme pada Anak}

Ibu merupakan salah satu pihak yang memiliki tanggung jawab dalam memantau pembelajaran dan penggunaaan literasi di media sosial yang dilakukan oleh anaknya. Tanggung jawab ini, meskipun merupakan tanggung jawab bersama antara ibu dan ayah, namun ibu memiliki peran yang besar dalam keberhasilan pembelajaran anak. Hal tersebut disebabkan peran ibu yang besar sebagai madrasah pertama anak. Sehingga dapat dikatakan bahwa unsur yang akan membentuk karakter dan pola pikir anak tentang agama adalah ibu. Salah satu hal yang perlu ditekankan dalam mengajarkan 
agama pada anak adalah pemahaman bahwa radikalisme bukanlah akhlak mulia, namun merupakan perbuatan mudarat. Sehingga nantinya anak dapat memahami bahwa konten diinternet yang mengandung radikalisme seperti ISIS atau terorisme tidaklah benar.

Istilah berbakti kepada kedua orang tua harus digaris bawahi sebagai sebuah tindakan yang dapat menjadi modal dalam menerapkan moderasi beragama melalui kepatuhan anak pada orang tuanya. Terlebih ketika orang tua mampu memberikan contoh tindakan yang serupa, maka jejak langkah kedua orang tua merupakan arah anak dalam melakukan kebaikan. Selain itu ajaran Islam yang mengedepankan prinsip rahmatan lil 'alamiin, sudah semestinya mampu mendorong mewujudkan perdamaian. Kaitannya dengan moderasi beragama, prinsip dan ajaran Islam ini dapat diwujudkan dengan kepatuhan anak pada orang tua ketika mengarahkannya untuk mempelajari Islam atau mencari sumber informasi yang benar dan dapat dipertanggung jawabkan. Misalnya dalam mengakses informasi melalui media sosial perlu ada pengarahan dari orang tua agar anak tidak mengakses konten yang mengarah pada radikalisme yang membahayakan pola pikir anak. Selanjutnya tugas anak adalah mematuhi apa yang diarahkan oleh orang tuanya sebagai salah satu wujud bakti anak pada orang tua.

Dalam Al-Qur'an telah dijelaskan, "Dan Tuhanmu telah perintahkan, supaya engkau tidak menyembah melainkan kepadaNya semata-mata dan hendaklah engkau berbuat baik kepada ibu bapak. Jika salah seorang dari keduanya atau kedua-duanya sekali, sampai kepada umur tua dalam jagaan dan peliharaanmu, maka janganlah 


\section{$e^{\text {I-Tarbawj Heny Kusmawati \& Anista Ika Surachman }}$}

engkau berkata kepada mereka (sebarang perkataan kasar) sekalipun perkataan " $\mathrm{Ha}$ " dan janganlah engkau menengking menyergah mereka, tetapi katakanlah kepada mereka perkataan yang mulia (yang bersopan santun).“. (QS. Al Isra': 23).

Salah satu bentuk bakti pada orang tua adalah dengan bertutur kata yang baik ketika berkomunikasi dengan orang tua. Bahkan dalam Islam, berkata "ah" pada orang tua saja termasuk dalam larangan karena dapat menyakiti perasaan orang tuanya. Sehingga dalam literatur lain juga dikatakan bahwa ridho Allah terdapat pada ridho orang tuanya. Karena itulah penting bagi anak untuk mematuhi apa yang dikatakan atau diajarkan orang tuanya terlebih apabila apa yang diajarkan oleh orang tua tersebut sejalan dengan ajaran Islam. Termasuk ketika orang tua menekankan untuk tidak mengakases konten yang mengarah pada radikalisme, maka seharusnya anak dapat memahami bahwa larangan tersebut bukan untuk membatasi anak belajar, tetapi untuk menjaga anak dari hal-hal yang membahayakan. Karena sebenarnya konten yang mengarah pada radikalisme dapat menimbulkan ketidakseimbangan dalam berpikir dan bergama.

Peran ibu dalam mengarahkan anaknya, khususnya pada kontroling dalam penggunaan media digital dapat dilakukan melalui memberikan pemahaman arti kebebasan positif (Parhan 2020, 172). Termasuk dalam proses mengajarkan moderasi beragama pada anak, ibu harus melakukannya dalam bentuk verbal maupun non verbal. Artinya, dalam prosesnya tidak hanya mencegah atau melarang, tapi juga ada contoh relevan yang dapat diamati oleh anak terhadap apa yang dilakukan ibunya. Misalnya ketika ibu melarang anak untuk 
mengakses konten media sosial yang mengarah pada radikalisme, maka ibu juga tidak boleh mengakses konten tersebut. Sehingga apa yang dikatakan oleh ibu relevan dengan perbuatan yang dicontohkannya. Peran ibu dalam mengontrol konten yang diakses anak secara tidak langsung menjadi modal untuk mewujudkan pola pikir anak yang seimbang. Menyeimbangkan pola pikir beragama ini sangat diperlukan sebagai bekal untuk mewujudkan pola pikir yang tidak mendeskriminasikan umat beragama lainnya. Selain itu, hal tersebut juga mampu mendorong untuk mewujudkan lingkungan sehat yang jauh dari kekerasan. Selanjutnya, hal yang perlu diperkuat dalam proses mengajarkan moderasi beragama pada anak adalah mngajarkan pentingnya bakti anak pada orang tuanya, termasuk pada Ibu. Hal ini menjadi aspek yang signifikan dalam upaya penguatan peran keluarga pada anak untuk mewujudkan moderasi beragama.

Sesuai dengan data penelitian, para ibu di Desa Babalan Kecamatan Gabus Kabupaten Pati yang memiliki anak usia 7-12 tahun menjelaskan bahwa tanggung jawab mengajar semenjak pandemi corona seolah menjadi tantangan baru dalam pendidikan di rumah. Namun, dengan terlibatnya orang tua secara langsung dalam seluruh proses pendidikan anak sebenarnya dapat meningkatkan kedekatan hubungan antara orang tua dengan anak (Cahyati\&Kusumah 2020, 152). Data penelitian menunjukkan $80 \%$ dari 50 ibu yang menjadi subjek penelitian, menyatakan sudah mengajarkan moderasi beragama dengan mengacu pada nilai-nilai yang terkandung dalam pancasila. Seperti yang diketahui bahwa setiap muatan nilai pancasila telah mendorong pola pikir dan perilaku dalam 


\section{$e^{\text {I-Tarbawj Heny Kusmawati \& Anista Ika Surachman }}$}

lingkungan dengan beragam agama, keyakinan, adat, maupun budaya. Misalnya dalam sila pertama yang membahas tentang beribadah, subjek penelitian telah mengajarkan anak rutinitas solat tepat waktu selama pandemi corona. Kemudian sila kedua tentang toleransi, dilakukan ibu dengan mengajarkan anak untuk menolong teman yang membutuhkan dalam hal kebaikan. Sila ke tiga tentang persatuan, dilakukan ibu dengan memberikan pemahaman bahwa persatuan itu dibutuhkan. Sebagai contoh ketika ada kerjabakti di desa, ibu mendorong anak untuk ikut berpartisipasi. Sila keempat yang menjelaskan tentang musyawarah, dilakukan ibu dengan membiasakan anak untuk berdiskusi tentang keinginan dan cita-cita mereka bersama orang tua. Pada sila terakhir, yaitu sila kelima tentang keadilan sosial, dilakukan ibu dengan menegaskan bahwa toleransi beragama itu penting untuk mewujudkan masyarakat yang harmonis. Salah satu langkah paling mudah yang dapat dilakukan oleh anak adalah dengan berlaku baik pada semua teman tanpa membedakan agama ataupun keyakinannya.

Upaya-upaya mengajarkan moderasi beragama melalui penanaman nilai pancasila dalam kehidupan sehari-hari cukup efektif untuk mengurangi resiko anak terpapar konten yang mengandung radikalisme. Data penelitian menunjukkan bahwa 70\% anak di Desa Babalan sudah tidak mengakses konten yang mengandung radikalisme. Konten yang mereka akses, terutama konten-konten terkait agama, mayoritas adalah konten pendidikan yang sesuai dengan arahan dari ibu dan guru. Langkah lain untuk meminimalisir peluang anak mengakses konten yang dilarang adalah dengan memanfaatkan peramban web khusus anak yang berfungsi memfilter informasi yang akan ditampilkan pada anak, misalnya 
menggunakan KidZui, Hoopah Kidview Computer Explorer, Peanut Butter PC, dan NoodleNet (Ulinnuha 2013, 341).

\section{Tahapan Mengajarkan Nilai-Nilai Pancasila yang Sesuai dengan Moderasi Keberagamaan di Lingkungan Tempat Tinggal.}

Pandemi Covid-19 telah mengubah tatanan pendidikan di Indonesia. Sejak Maret 2020 siswa sekolah melakukan pembelajaran secara daring. Pembelajaran tersebut membuat siswa hanya belajar dari rumah, tak terkecuali siswa yang berusia 7-12 tahun. Kebijakan pelaksanaan pembelajaran daring tersebut sesungguhnya berorientasi pada keselamatan peserta didik, guru, dan tenaga kependidikan dan masyarakat secara umum (Nurkamiden 2021, 164). Pelaksanaan pembelajaran daring dapat disesuaikan dengan kebutuhan masing-masing sekolah, salah satu contohnya adalah dengan pemberian penugasan. Penugasan yang diberikan selama pembelajaran daring membuat siswa banyak mengakses internet untuk membantu dalam pengerjaan tugas. Penggunaan internet dalam pembelajaran mengalami peningkatan yang signifikan dan situs yang diakses pun semakin beragam. Kemudahan dalam mengakses internet dengan beragam konten yang ada di dalamnya, dapat memicu munculnya tindakan negatif apabila pada prosesnya tidak ada kontrol dari orang tua. Hal ini menjadi mengkhawatirkan terlebih anak-anak belum mampu menyeimbangkan antara konten positif dan negatif. Apalagi kecenderungan pada anak baru sebatas melakukan apa yang mereka sukai, tidak mempertimbangkan dampak hal tersebut ataupun bagaimana kaidah agama yang terkait dengannya. Maka dari itu, orang tua memiliki peran penting dalam 


\section{$e^{\text {I-Tarbawj Heny Kusmawati \& Anista Ika Surachman }}$}

pencegahan anak mengakses literasi yang mengarah pada radikalisme dengan mengajarkan nilai-nilai pancasila yang sesuai moderasi beragama. Kelima sila dalam pancasila, dapat diwujudkan dalam langkah-langkah konkret untuk menanamkan moderasi pada anak.

\section{a. Sila pertama, Ketuhanan Yang Maha Esa}

Sila pertama yang berbunyi "Ketuhan yang maha esa" menunjukkan keberagamaan menjadi nilai penting dalam kehidupan. Hal tersebut juga didukung oleh posisi pernyataan ini yang ditempatkan pada sila pertama. Melibatkan Tuhan dalam setiap aktivitas yang dilakukan oleh manusia, merupakan manifestasi dari sila tersebut. Setiap manusia memiliki kewajiban yang harus mereka lakukan sebagai seorang hamba. Kewajiban ini tidak hanya melekat pada satu tahapan perkembangan manusia, namun akan terus dibawa meskipun manusia terus berkembang dan mengalami perubahan (Jannah 2015, 87). Selain itu manusia diciptakan bukan hanya sebagai makhluk individu yang hanya mengerjakan kewajiban-kewajibannya sebagai individu saja. Manusia juga memiliki peran sebagai makhluk sosial yang dalam interaksinya dengan orang lain tetap harus berpedoman pada ajaran agama. Terkait dengan hal tersebut, adanya keluarga khusunya ibu memiliki peran penting untuk menanamkan nilai agama sejak dini pada anak-anaknya. Nilai ini akan menjadi bekal untuk anak tersebut dalam menjalankan perannya sebagai makhluk individu maupun makhluk sosial. Salah satu nilai yang harus ditanamkan sejak kecil adalah nilai toleransi. Ajaran tiap agama mewajibkan seseorang 
menyembah Tuhan yang dipercayai dan diimani. Saat ini, terdapat enam agama yang diakui di Indonesia. Hal tersebut menunjukkan keberagaman keyakinan yang dianut oleh warga negara Indonesia. Perbedaan dalam agama seharusnya tidak menjadikan sebuah permasalahan yang menjadikan satu dengan lainnya tidak rukun. Hal ini perlu menjadi perhatian dalam keluarga, khususnya Ibu untuk mengajarkan toleransi dalam beribadah. Misalnya keluarga muslim yang sehari-hari melaksanakan sholat dan mengaji, perlu memberikan pemahaman bahwa penganut agama lain beribadah pada Tuhannya dengan cara lain. Pemahaman ini dapat digunakan sebagai bekal untuk anak dalam berinteraksi dengan siapapun dengan tetap menghargai perbedaan yang ditemui.

Hal tersebut sesuai dengan contoh yang dipaparkan dalam buku saku Kemenag tentang moderasi beragama. Dicontohkan ketika seseorang sedang beribadah, lalu ada orang lain di dekatnya yang hampir mati akibat terjatuh ke dalam sumur, maka dia wajib membatalkan ibadahnya untuk kemudian membantu saudaranya yang terjatuh ke dalam sumur itu. Ibadah kepada Tuhannya bisa ia lakukan setelah menolong saudaranya itu. Contoh selanjutnya, seorang dokter harus bergegas menunaikan kewajiban beribadah. Namun di saat yang sama ada pasien dalam kondisi darurat harus segera ditangani dan tidak dapat ditangguhkan. Dalam kondisi seperti itu, dokter harus segera menyelamatkan pasiennya dan menunda ibadahnya, pelaksanaan kewajiban agamanya dapat dilakukan setelah menolong pasien tersebut. Watak kemanusiaan yang seperti ini dapat membawa seseorang yang beragama untuk dapat menghargai alam dan nyawa makhluk 


\section{$e^{\text {I-Tarbawj Heny Kusmawati \& Anista Ika Surachman }}$}

semesta lainnya. Contoh lain yang berkaitan dengan ibadah, misalnya ketika seseorang yang hendak melaksanakan shalat harus bersuci dan berwudlu terlebih dahulu dengan air. Andai suatu ketika ia hendak berwudlu namun kondisi airnya terbatas, padahal di sampingnya ada anjing yang membutuhkan air untuk minum, ia harus bisa memprioritaskan mana yang harus didahulukan. Pilihan yang bisa diambil salah satunya adalah menolong anjing itu lalu mencari alternatif lain untuk bersuci, misalnya bertayamum atau bersuci dengan debu (Kemenag RI 2019, 1-2). Berkaitan dengan contoh-contoh tersebut, keluarga khususnya ibu harus menjelaskan bahwa agama harus mampu menanamkan semangat keseimbangan. Agama harus diamalkan untuk menebarkan rahmat dan kasih sayang bagi alam dengan segala isinya. Dengan begitu, anak akan terbiasa mengasihi orangorang di lingkungannya terutama dengan orang tuanya.

b. Sila Kedua Kemanusiaan Yang Adil dan Beradab

Dalam moderasi beragama sila kedua yang berbunyi "Kemanusia yang adil dan beradab" dapat dikategorikan dalam nilai kemanusiaan. Nilai-nilai kemanusiaan yang berkaitan dengan nilai-nilai karakter bangsa diantaranya adalah kebenaran, kebajikan, kedamaian, kasih sayang, dan tanpa kekerasan (Sukayasa 2015, 54). Berdasarkan hal tersbeut, sila kedua harus diajarkan kepada anak untuk membentuk sikap menolong, berempati, dan bersimpati dengan orang lain. Di masa pandemi covid 19, ada contoh nyata yang dapat diterapkan langsung terkait ketiga sikap diatas. Misalnya anak harus ditanamkan untuk peduli dengan orang lain dengan cara 
memakai masker, face shield, dan cuci tangan untuk menolong diri sendiri dan orang lain untuk meminimalisir penyebaran wabah. Namun pada pelaksanaannya masih banyak anak yang belum memahami hal tersebut, sehingga tugas ibu untuk mengajarkan hal tersebut. Nilai kemanusiaan harus tertanam dalam jiwa anak agar mereka mudah berempati dengan orang lain dan tidak mementingkan ego sendiri

Jika dikaitkan dengan sila pertama, tidak seharusnya seseorang atas nama ajaran agama melakukan perbuatan yang merendahkan harkat, derajat, dan martabat kemanusiaan, atau bahkan menghilangkan nilai kemanusiaan. Misalnya melakukan tindakan yang berlebihan atau ekstrem dengan dalih jihad agama, seperti meledakkan bom di tengah supermaket lalu puluhan bahkan menewaskan ribuan orang. Perbuatan tersebut bukan merupakan pembelaan terhadap agama, bahkan tidak sesuai dengan sila ke dua. Ada banyak cara untuk bermanfaat bagi orang lain contohnya adalah menyantuni anak-anak yatim piatu dan berbagi kepada yang membutuhkan. Ibu memiliki peran utama untuk mengajarkan anak melakukan hal tersebut.

\section{c. Sila Ketiga Persatuaan Indonesia}

Indonesia adalah negara dengan semboyan Bhinneka Tunggal Ika yang artinya berbeda-beda tetapi tetap satu jua. Perbedaan suku, ras, dan agama bukan satu hal yang harus dijadikan permasalahan yang membuat seseorang bisa mendiskriminasikan pihak lain yang berbeda dengannya. Pada sebuah hadis dinyatakan "lakum dinukum waliyadin" yang menjelaskan bahwa beragama adalah urusan masing-masing, 


\section{$e^{\text {I-Tarbawj Heny Kusmawati \& Anista Ika Surachman }}$}

agamamu adalah agamamu dan agamaku adalah agamaku. Pemahaman ini harus ditanamkan pada anak sejak dini, sehingga anak memiliki pemahaman bahwa antara ia dan temannya tidak harus memiliki kepercayaan yang sama. Semua agama pada hakikatnya baik, sehingga perbedaan agama bukanlah salah satu faktor yang dapat memecah belah persatuan Indonesia. Indonesia dengan kearifan lokal dan terkenal dengan masyarakatnya yang ramah merupakan salah satu cerminan moderasi beragama yang memuat nilai kesepakatan bersama demi terciptanya persatuan. Sikap gotong royong dan menghargai perbedaan yang ditunjukkan oleh anak adalah salah satu cermin keberhasilan ibu dalam mengajarkan sila ke tiga pancasila kepada anak.

d. Sila Keempat, Kerakyatan Yang Dipimpin Oleh Hikmat Kebijaksanaan Dalam Permusyawaratan Perwakilan

Unsur sila ke empat juga memuat nilai moderasi berupa kesepakatan bersama. Membangun sebuah kesepakatan merupakan tantangan dalam kehidupan bermasyarakat terutama di masa pandemi Covid-19. Kondisi keterbatasan interaksi memunculkan asumsi bahwa pandemi ini mampu memecah belah sebuah bangsa. Untuk melatih kesepakatan pada anak, anak harus dipandu dan diberikan pemahaman bahwa adanya protokol kesehatan yang diterapkan untuk mencegah Covid-19 dibuat untuk ditaati, tidak untuk dilanggar. Selain itu dengan kemudahan akses ke dunia maya, ibu juga harus membekali pemahaman bahwa kebebasan berpendapat tidak harus diutarakan melalui media sosial atau memberikan berita yang belum jelas kebenarannya. Penting 
pula mengajarkan pada anak untuk menghargai agama lain dan orang lain demi kemaslahatan umat. Selain itu, kaitannya dengan proses pembelajaran, kesepakatan bersama antara guru dan orang tua dapat digunakan untuk mendisiplinkan anak yang prosesnya dilakukan melalui tiga tahap negosiasi (Kusumawardani dkk 2020, 25).

Termuat dalam buku saku Kemenag RI bahwa jika seseorang, atas nama ajaran agama, melanggar butir-butir Pancasila, Undang-undang Dasar 1945, dan Negara Kesatuan Republik Indonesia (NKRI), yang telah menjadi kesepakatan bersama bangsa Indonesia dalam berbangsa dan bernegara, dapat dikategorikan sebagai perbuatan ekstrem dan melanggar. Dalam kehidupan bermasyarakat, banyak peraturan yang telah disepakati bersama oleh seluruh warga disuatu lingkungan. Jika seorang warga, atas nama agama yang dianutnya, melanggar kesepakatan bersama yang telah menjadi kesepakaran bersama tersebut, maka ia dapat dianggap berlebih-lebihan (Kementerian Agama RI 2019).

\section{e. Sila kelima, Keadilan Sosial Bagi Seluruh Rakyat Indonesia}

Dunia anak adalah dunia bermain, karna itulah bermain menjadi salah satu aktivitas utama yang ditunggu anak seharihari. Melalui bermain, anak dapat mengembangkan kreativitasnya dan belajar mengkreasikan pengetahuan melalui proses interaksi dengan teman bermainnya (Priyanto 2014, 41). Ibu sebagai sosok penggerak memiliki kemampuan menanamkan ketertiban umum kepada anak agar tidak melanggar peraturan ketika bermain bersama temannya. 


\section{$e^{\text {I-Tarbawj Heny Kusmawati \& Anista Ika Surachman }}$}

Keharusan mematuhi ketertiban umum merupakan salah bentuk sila keadilan. Dengan keseimbangan dalam kehidupan sosial kemasyarakat maka akan terbentuk keadilan sosial bagi seluruh rakyat Indonesia.

Pemaparan di atas menunjukkan posisi yang jelas antara agama dan beragama. Agama adalah ajaran yang diperintahkan, sedangkan beragama adalah sikap dalam mengamalkan ajaran tersebut. Anak harus mampu membedakan hal tersebut agar mampu menyeimbangkan pengetahuan agama dengan sikap yang dimilikinya sebagai bentuk moderasi beragama. Terkait dengan hal tersebut, moderasi beragama adalah bagian dari strategi memelihara bangsa Indonesia. Para pendiri bangsa sudah berhasil mewariskan satu bentuk kesepakatan dalam berbangsa dan bernegara, yakni Negara Kesatuan Republik Indonesia, yang telah nyata berhasil menyatukan semua kelompok agama, etnis, bahasa, dan budaya. Indonesia disepakati bukan negara dari satu agama saja, tapi juga tidak memisahkan agama dari kehidupan sehari-hari warganya. Perpaduan nilai agama dengan kearifan lokal dan adat istiadat merupakan sebuah moderasi beragama yang harus senantiasa dilaksanakan. Perpaduan ini Nampak pada beberapa hukum agama yang dilembagakan oleh negara dan kolaborasi ritual agama serta budaya yang rukun dan damai. 


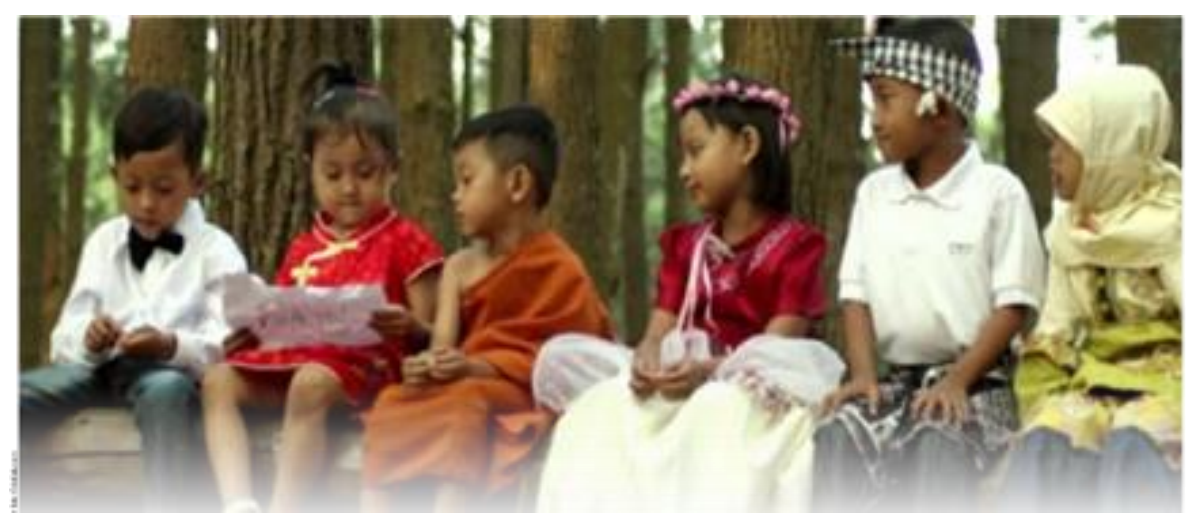

GAMBAR 1. Anak dan moderasi beragama

Sumber: Buku Tanya Jawab Moderasi Beragama Karangan Kemenag RI

Berdasarkan data-data penelitian dan analisis teori yang digunakan, Ibu di Desa Babalan Kecamatan Gabus Kabupaten Pati telah mempraktikkan moderasi beragama melalui pencegahan dan pembatasan akses literasi radikalisme dengan menerapkan nilai-nilai pancasila dalam pendidikan anak dalam keluarga. Anak sebagai harta yang paling berharga, sejak dini perlu dibekali pendidikan yang dapat membentuk karakternya untuk mampu bertoleransi kepada agama dan lingkungan sekitarnya. Ketika moderasi beragama telah mampu terinternalisasi, maka akan mewujukan kehidupan bermasyarakat yang rukun. Apalagi selama pandemi Covid-19 yang mengharuskan anak-anak belajar dari rumah, ibu memiliki peran yang besar dalam terlaksananya pendidikan.

\section{KESIMPULAN}

Upaya pencegahan akses literasi radikalisme oleh anak di dunia maya dilakukan dengan langkah verbal dan non verbal. Tindakan yang mendorong upaya tersebut dikonkritkan dalam 


\section{$e^{\text {I-Tarbawj Heny Kusmawati \& Anista Ika Surachman }}$}

tindakan nyata yang diajarkan oleh ibu kepada anak. Tahapan mengajarkan nilai-nilai pancasila yang sesuai dengan moderasi keberagamaan di lingkungan tempat tinggal dilakukan dengan menerapkan nilai-nilai Pancasila. Nilai-nilai tersebut diantaranya adalah mengajarkan sila pertama dan kedua yang memuat nilai kemanusiaan, sila ketiga dan keempat yang mengandung nilai kesepakatan bersama, dan sila kelima yang memuat nilai ketertiban umum.

\section{DAFTAR PUSTAKA}

Budiasih, I Gede Ayu Nyoman. (2014). “Metode Grounded Theory dalam Riset Kualitatif", Jurnal Ilmiah Akuntansi dan Bisnis, Vol. 9, No. 1. 10.7454/jki.v13i2.241

Cahyati, Nika dan Rita Kusumah. (2020). “Peran Orang Tua dalam Menerapkan Pembelajaran di Rumah Saat Pandemi Covid-19", Jurnal Golden Age, Vo. 4, No. 1.

Emzir. 2018. Metodologi Penelitian Pendidikan Kuatitatif dan Kualitatif. Jakarta: Rajawali Press.

Fahri, M dan Zainuri. (2019). "Moderasi Beragama di Indonesia", Jurnal Intizar, Vol. 25, No.2. https://doi.org/10.19109/intizar.v25i2.5640/

Hiqmatunnisa, Hani dan Ashif Az Zafi. (2020). “Penerapan Nilai-Nilai Moderasi Islam Dalam Pembelajaran Fiqih di PTKIN Menggunakan Konsep Problem Basic Learning", Jurnal JIPIS, Vol. 29, No. 1. https://doi.org/10.33592/jipis.v29i1.546

Jannah, Miftahul. (2015). “Tugas-tugas Perkembangan Pada Usia Kanak-kanak", Gender Equality: International Journal of 
Child and Gender Studies, Vol. 1, No. 2. http://dx.doi.org/10.22373/equality.v1i2.792

Jasuri. (2015). "Pembelajaran Pendidikan Agama Islam pada Anak Usia Dini", Jurnal Madaniyah, Vol. 8.

Junaedi, Edi. (2019). “Inilah Moderasi Beragama Perspektif Kemenag", Jurnal Harmoni, Vol. 18, No. 2. 10.32488/harmoni.v18i2.414

Kementrian Agama RI. (2019). Tanya Jawab Moderasi Beragama?. Jakarta: Badan Litbang dan Diklat Kemenag RI.

Khatimah, Husnul. (2020). "Internalisasi Moderasi Beragama dalam Kurikulum Pesantren", Jurnal Rabbani, Vol. 1, No. 1. http://dx.doi.org/10.19105/ripal.v1i1.2008

Kusumawardani, Nuralita, Tri Rejeki, dan Afia Fitriani. (2020). "Membangun Kesepakatan Antara Orang Tua dan Guru Tentang Cara Mendisiplinkan Siswa Di Sekolah", Indigenous: Jurnal Ilmiah Psikologi, Vol. 5, No. 1. https://doi.org/10.23917/indigenous.v5i1.7862

Kusmawati, Heny. (2019). Strategi Belajar Mengajar di Era Distrupsi. Pati: Al Qolam.

Nurkamiden, Ulfa. (2021). “Kebijakan Pendidikan di Indonesia Era Pandemi Covid-19", Tadbir: Jurnal Manajemen Pendidikan Islam, Vol. 9, No. 2. https://doi.org/10.30603/tjmpi.v9i2.2264

Parhan, Muhammad dan Dara Puspita. (2020). “Aktualisasi Peran Ibu Sebagai Madrasah Pertama dan Utama Bagi Anak di Era 4.0", Journal of Madrasah Ibtidaiyah Education, Vol. 4, No. 2. http://dx.doi.org/10.32934/jmie.v4i2.193 


\section{el-Tarbawj Heny Kusmawati \& Anista Ika Surachman}

Priyanto, Aris. (2014). "Pengembangan Kreativitas Pada Anak Usia Dini Melalui Aktivitas Bermain", Jurnal Ilmiah Guru "COPE", No. 2.

Raaco, J. (2010). Metode Penelitian Kualitatif: Jenis, Karakteristik dan Keunggulannya. Jakarta: PT. Grasindo.

Sukayasa, Evie Awuy. (2015). “Pengintegrasian Nilai-Nilai Kemanusiaan (Human Values) dalam Pembelajaran Tematik Sekolah Dasar", Jurnal Kreatif, Vol. 17, No. 2.

Sutrisno, Edy. (2019). "Aktualisasi Moderasi Beragama di Lembaga Pendidikan", Jurnal Bimas, Vol. 12, No. 1. https://doi.org/10.37302/jbi.v12i2.113

Syahid, Imam Muhammad. (2015). Peran Ibu Sebagai Pendidik Anak dalam Keluarga Menurut Syekh Sofiudin bin Fadli Zain, Tesis pada Universitas Islam Negeri Walisongo.

Ulinnuha, Masyari. (2013). “Melindungi Anak dari Konten Negatif Internet: Studi Terhadap Peramban Web Khusus Anak", Sawwa: Jurnal Studi Gender, Vol. 8, No. 2. 